\title{
Possible Geological Reason for the Missing of the Oligocene Section in Sector (5) and Its Vicinity, Deryanah-Al Abyar Area, Al Jabal Al Akhdar, NE Libya
}

\author{
Omar B. Elfigih, Hamza S. Melad \\ Department of Earth Sciences, Faculty of Science, University of Benghazi, Benghazi, Libya \\ Email: oelfigih@yahoo.com, hamza_saleh1987@yahoo.com
}

Received April 21, 2013; revised May 24, 2013; accepted June 25, 2013

Copyright (c) 2013 Omar B. Elfigih, Hamza S. Melad. This is an open access article distributed under the Creative Commons Attribution License, which permits unrestricted use, distribution, and reproduction in any medium, provided the original work is properly cited.

\begin{abstract}
The existing stratigraphic framework of the Eocene-Miocene in the study area (sector 5) shows limited temporal stratigraphic and structural resolution. Using this framework, it is difficult to unravel the influence of possible local tectonic movements and eustatic sea level changes on sedimentation. The precise influence of the onset of the possible Late Eocene-Early Oligocene orogenic phase, which caused inversion and uplift in the study area (sector 5), is also dubious as a result of the limited data. To improve the correlations and recognition of the Eocene to Oligocene successions in the area in question (from sector 1 to sector 8), a new stratigraphic interpretation, based on correlated lithostratigraphic columns from different outcrops, is presented. The changes in sedimentation and tectonic events in the study area can be correlated to time-equivalent sea level changes and tectonic uplift in $\mathrm{Al} \mathrm{Jabal} \mathrm{Al} \mathrm{Akhdar} \mathrm{area,} \mathrm{which} \mathrm{suggests} \mathrm{that}$ the processes causing the sedimento/structural activity are of regional importance.
\end{abstract}

Keywords: Sector 5; Oligocene; Inversion; Uplift; Stratigraphic Correlation

\section{Introduction}

\subsection{Location of the Study Area}

The study area (Figure 1) is located in the northwestern part of Al Jabal Al Akhdar and consists of eight sectors (sectors 1 - 8), covering an area of about $100 \mathrm{~km}^{2}$. There are at least nine wadis running from SE to NW direction, parallel to each other, formed by channel incision followed by deepening and widening processes under the influence of erosion and tectonics.

\subsection{Lithostratigraphic Framework}

The stratigraphic framework of the recognized EoceneMiocene section in sector (5) shows few information (Figure 2) as a result of the limited data available for this interval. The data from detailed outcrops information from (sectors 1 - 8) (Figure 3) are only available to reveal more proximal understanding to the depositional settings, and to unravel the relative influence of local tectonics and sea level variations on the Eocene-Mioc- ene sedimentation in the area in question.

\subsection{Objectives}

The aims of this study are to introduce a new, best facies fit correlation approach and stratigraphic interpretation between studied columns, and to detect some possible reasons for the absence of the Oligocene section in sector (5).

\section{Methodology}

The method is based on the construction of regional best facies fit correlation between sectors (1 to 8). Cyclic sequences were interpreted from lithologic description based on hand specimen samples derived from outcrop columns. The descriptions provide information on sediment composition and grain size, sediment colour and the occurrence of constituents such as chert, mud clasts, glauconite, and fossils. This construction method enables a high-resolution correlation between the Eocene-Oligocene tectono-stratigraphic evolution of the study area as a part of the geology of NE Libya. 


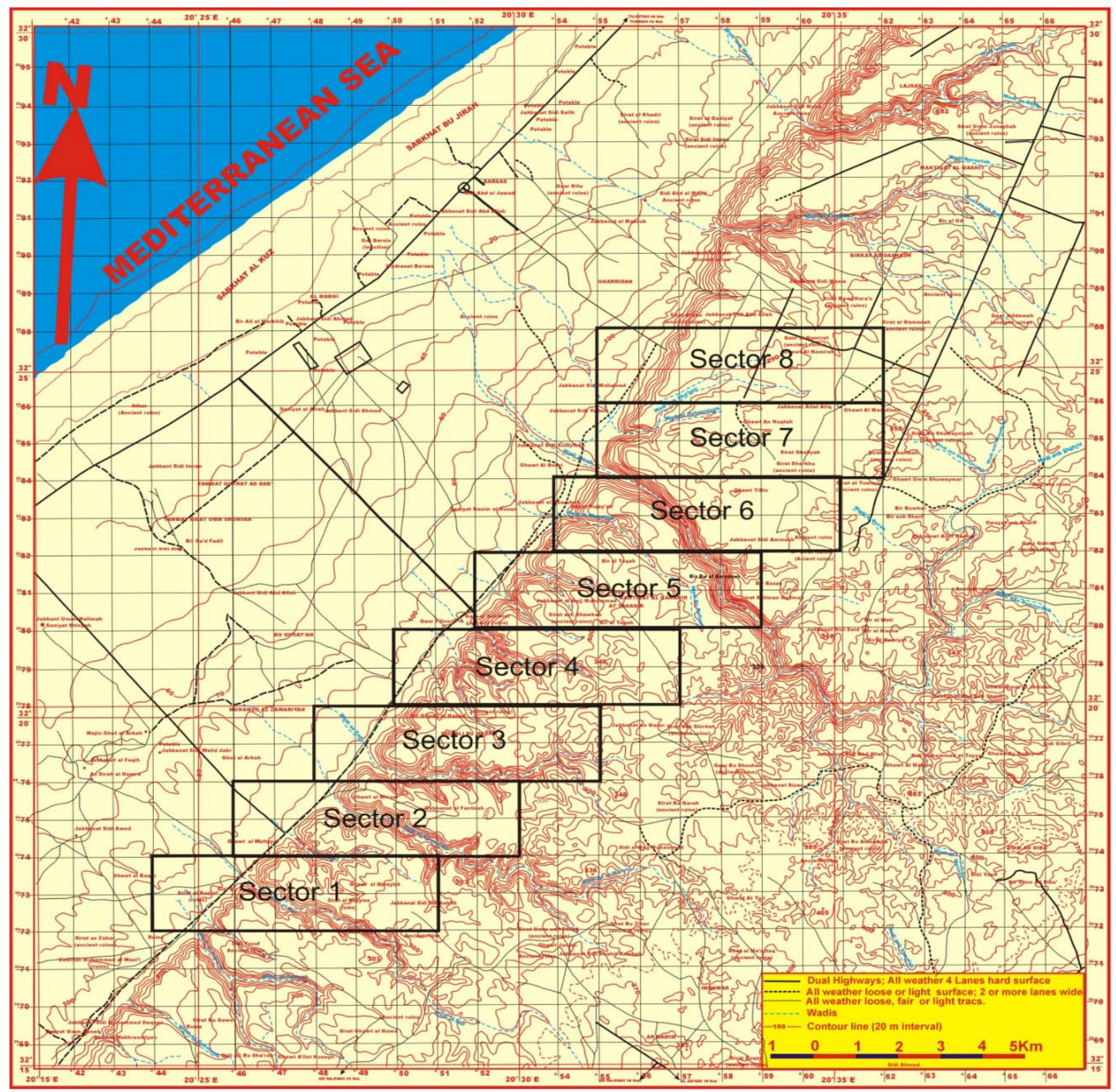

Figure 1. Location map of the study area (sector 5$)$.

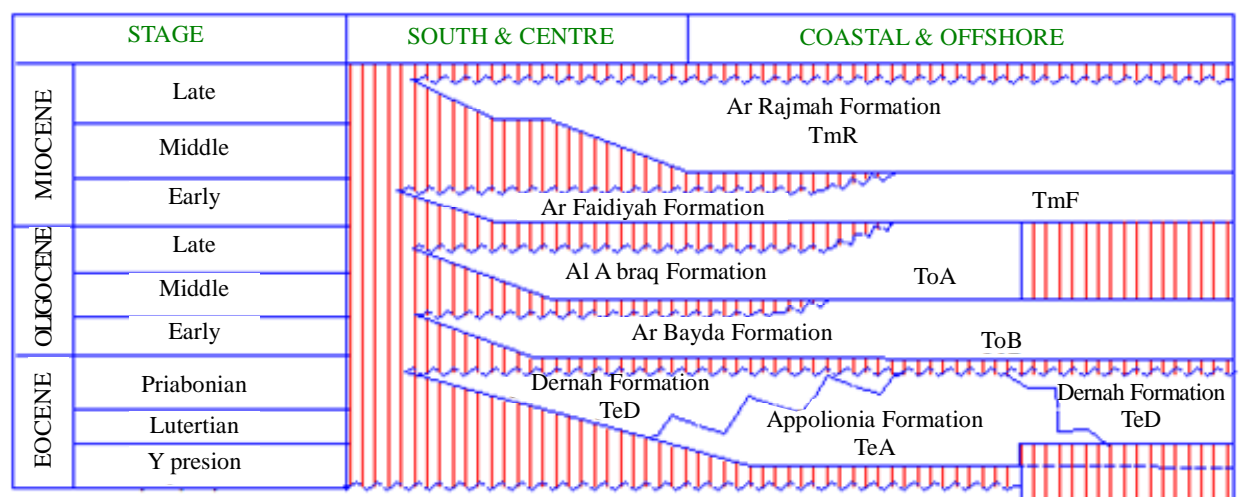

Figure 2. Stratigraphic chart of Al Jabal Al Akhdar, NE Libya. From [1]. 


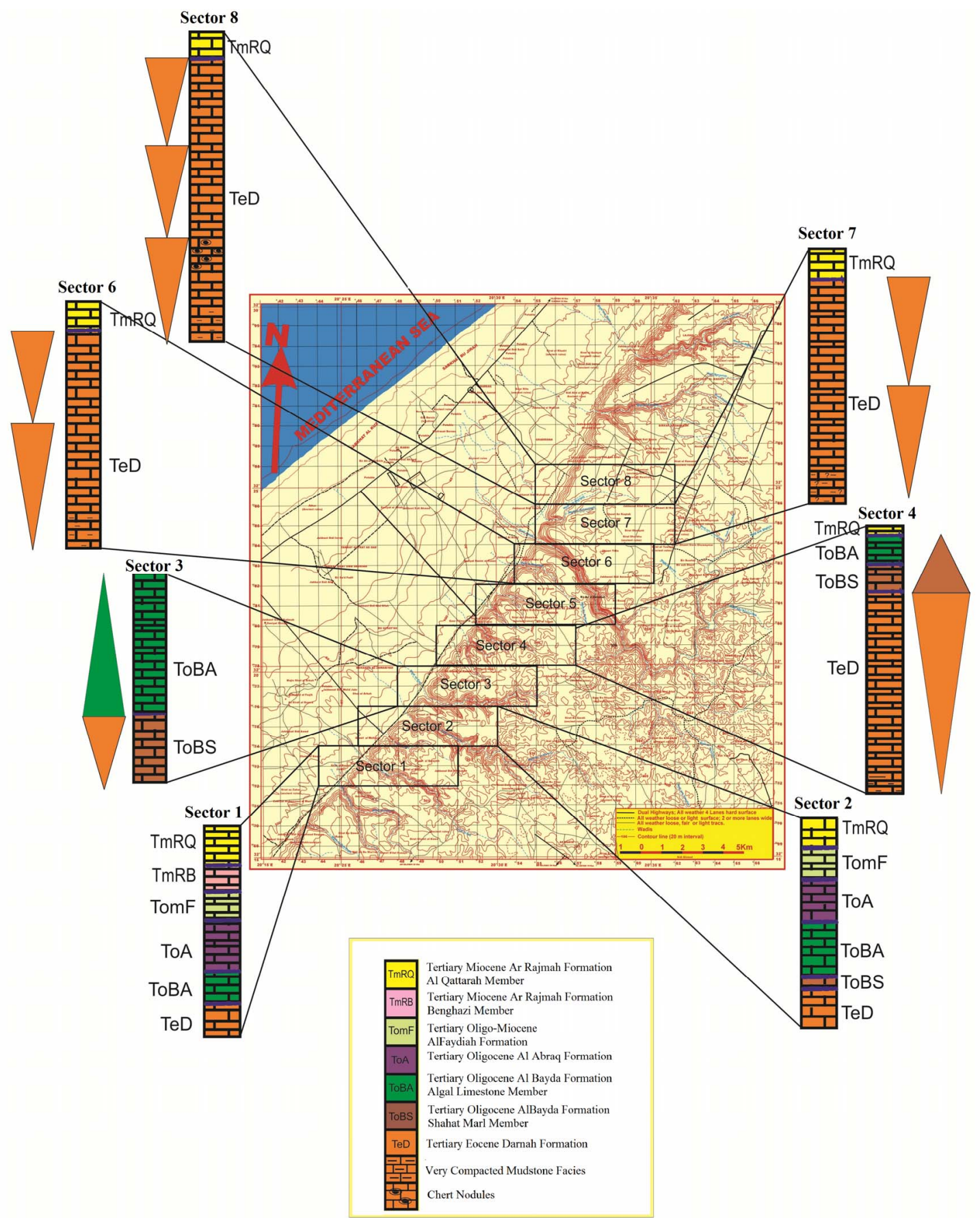

Figure 3. Detailed outcrop information from sectors (1 - 8) (Data of sectors 1 - 4 and 6 - 8 are from [2]).

\section{Regional Tectonic Setting}

\subsection{In Al Jabal Al Akhdar Area}

According to [3], during Eocene-Oligocene to Middle Miocene Al Jabal Al Akhdar (Figure 4, stages 3 \& 4) was affected by uplifting tectonics associated with faulting while Cyrenaica platform was partially subsiding. Hence, tectonically undisturbed Early to Middle Eocene sequence, which reflects the eustatic sea level rise is lo- cated deep in the basin while general reduction of these sediments take place close to the basin margin. Latter, Late Eocene-Oligocene succession was affected most by post-depositional tectonic movements and erosion marking sea level dropping.

\subsection{In North Africa}

On broad scale the geological evolution of North Africa from Mesozoic to Cenozoic can be viewed as a response 


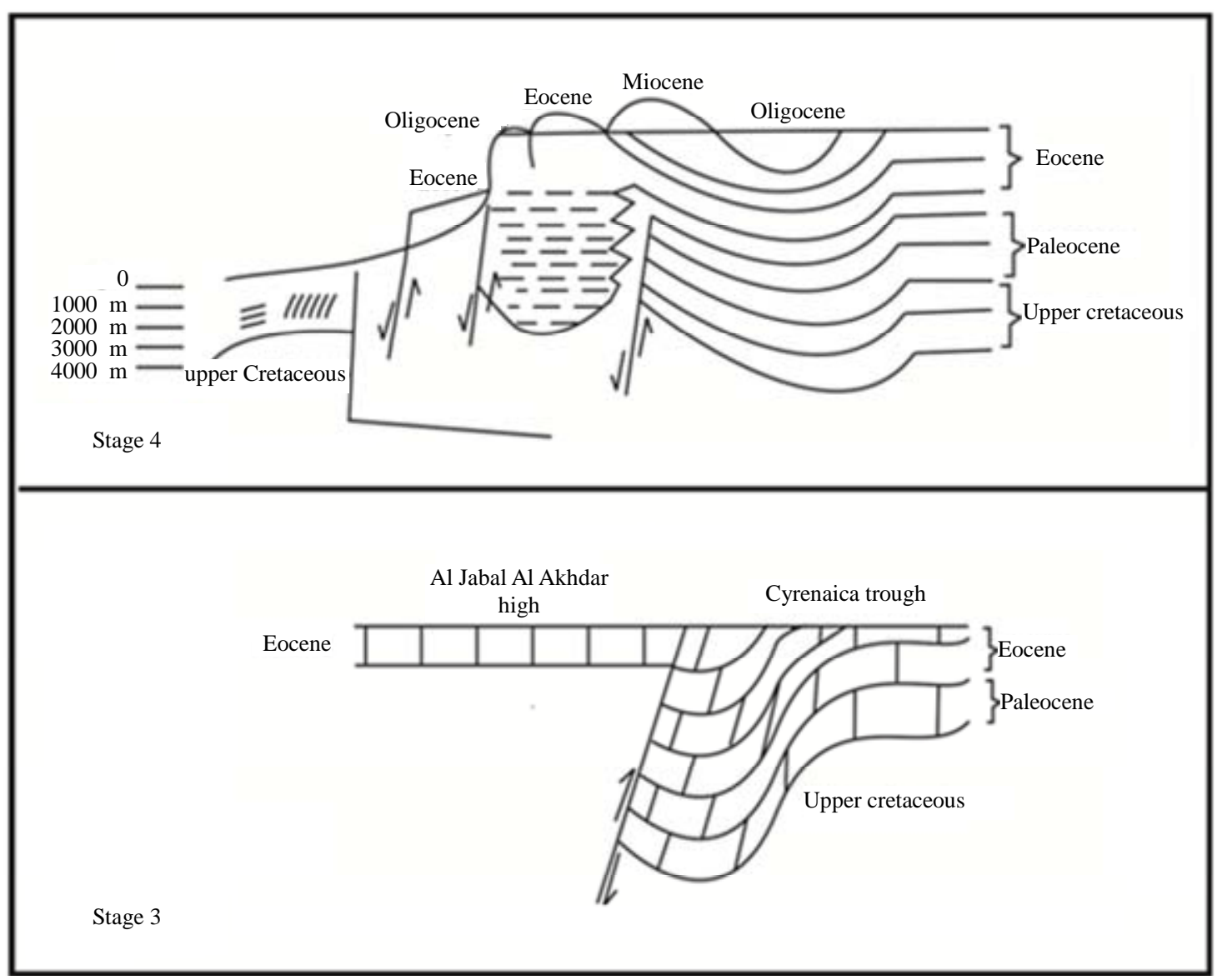

Figure 4. Structure development of Al Jabal Al Akhdar; stages 3 and 4. From [3].

to two major geological events which are:

1) The opening of the North Atlantic and the western Tethys in the early Mesozoic.

2) The African-Europe continental collision in the Middle Cenozoic [4-8].

As an example of these tectonic activities, the Atlas system evolved within the stable platform of North Africa, has been shaped by two major events: Early Mesozoic extension and rifting, and Mesozoic-Cenozoic compressional-transpressional phase that resulted in the inversion of the rift system [9] (Figure 5).

High strain rates created by the thinning of the continental lithosphere resulted in the deformation of the crust by extension and rifting in the North African plate at the end of the Permian and beginning of the Triassic [10]. Sedimentation rates accelerated through the Jurassic as rifting continued with the breakup of Pangaea, and the opening of the neo-Tethys Ocean and the North Atlantic [11].

Beginning in the Late Cretaceous-Early Oligocene, dextral movement on the Newfoundland-Gibraltar fault zone increased the eastward drift of the Iberian plate [10]. The geometric relationship between the Iberian plate and the African plate resulted in compressional stresses that were transferred to the North African rift system. The bulk of the intraplate stresses were absorbed by the High and Middle Atlas rift system resulted in shortening and subsequence inversion. The inversion of these rifts led to the reactivation of preexisting Mesozoic and Hercynian fault into reverse and thrust fault, with an oblique-slip sense of movement. The uplift of the Middle and High Atlas rifts formed the mountains that are now the boundaries of the Missour basin.

\section{Regional Stratigraphic Setting}

On plane view (Figure 6), moving from the southwest towards the northeast of the studied area, the carbonate rocks of Oligocene age topped by Miocene rocks are progressively changing laterally to carbonate rocks of Eocene rocks topped by Miocene rocks, where the Oligocene rocks is missing.

Vertically, at each studied sector, change of grain size, from a fining, to a coarsening upward cycle (Figure 3) especially in Darnah Formation of Eocene age. Most sedimentary units consist of fine mudstone facies deposited in an open marine shelf setting, while coarser grainstone facies are, indicating coastal settings displaying a 


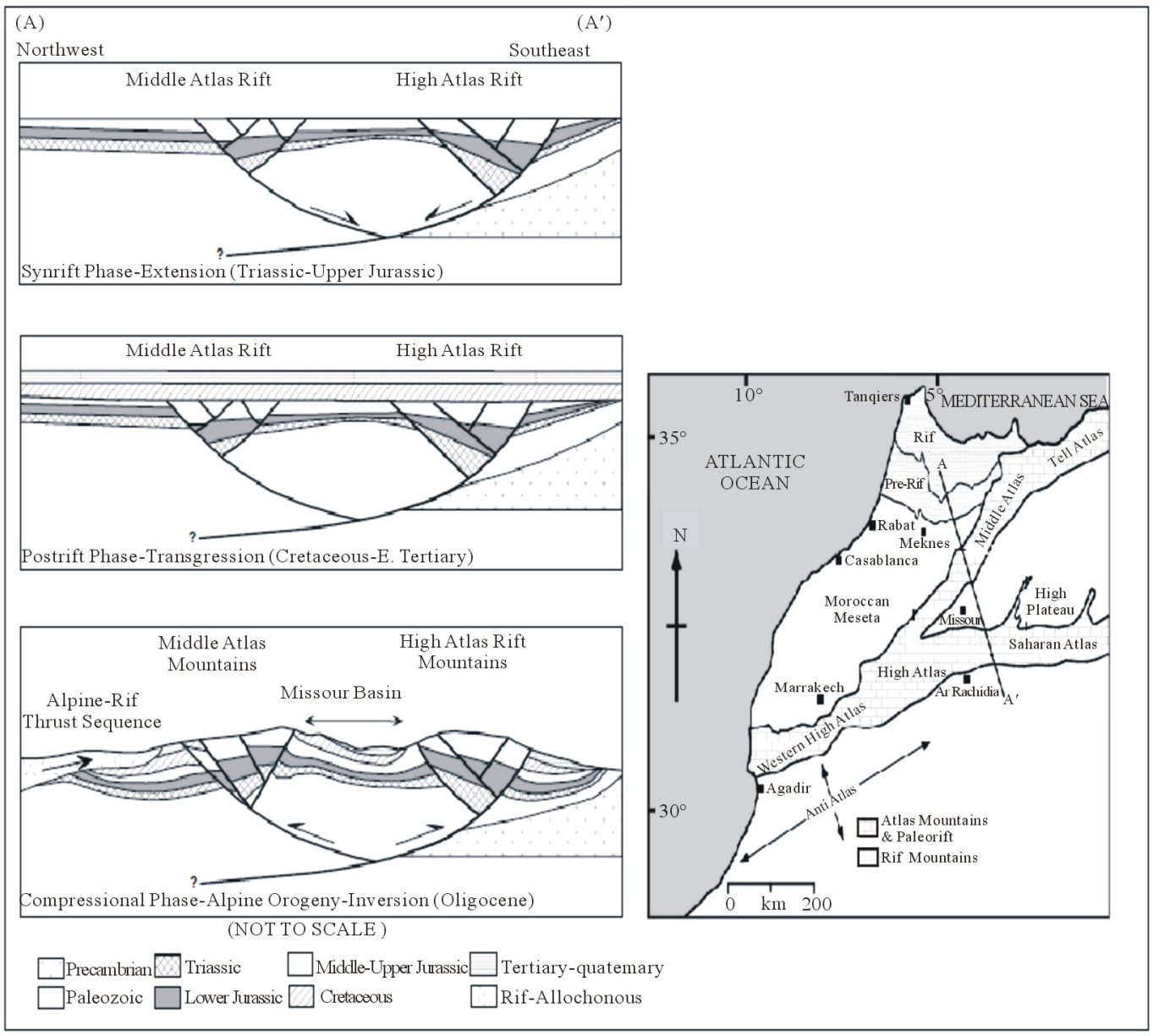

Figure 5. Conceptual model for the development of the Missour Basin and Atlas Mountains, Morocco. From [9].

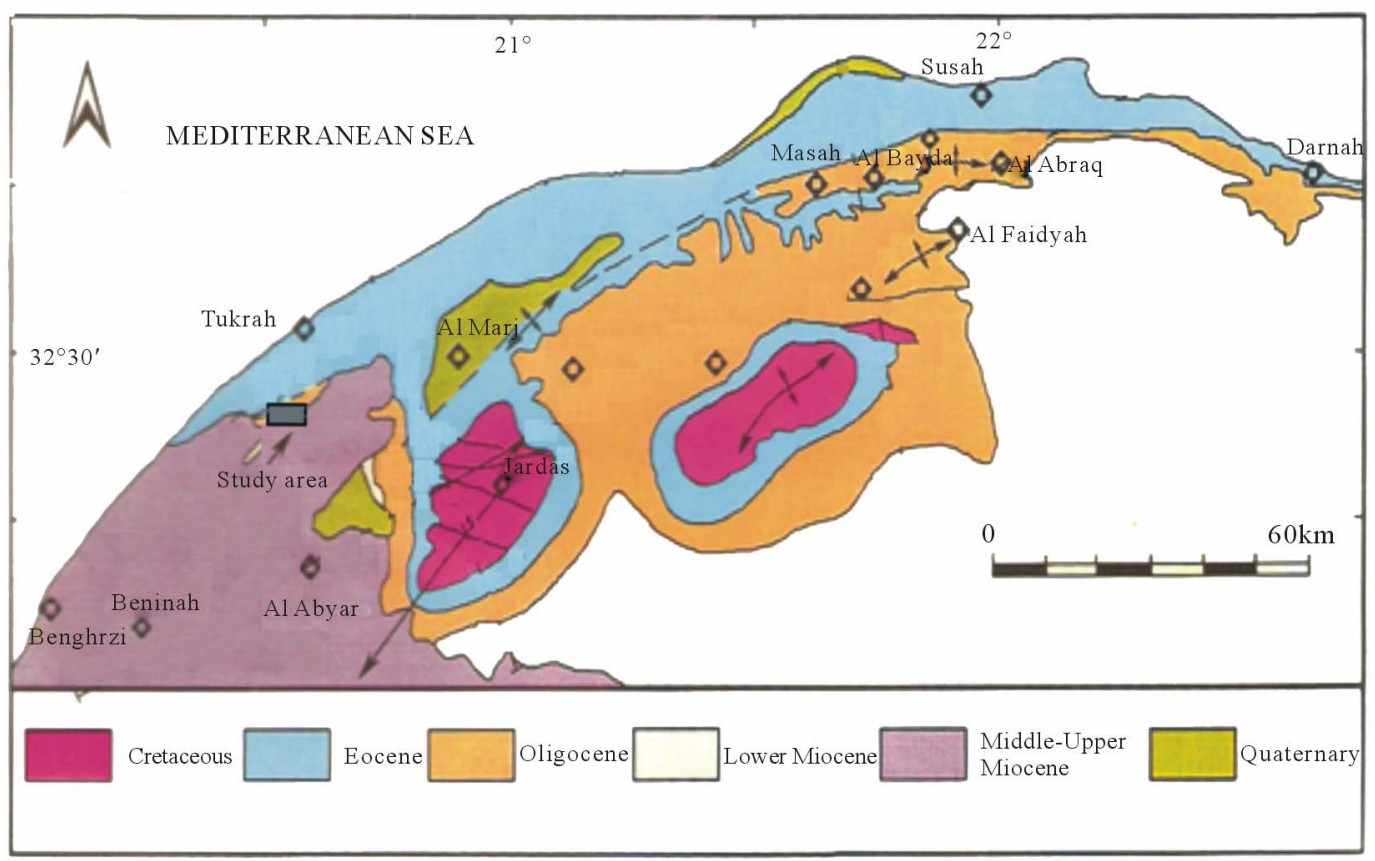

Figure 6. Geological surface map of Al Jabal Al Akhdar and the study area. Adapted from [1]. 
distinct regressive mode.

This suggests a local relative sea level drop, and a reduction in accommodation space, during deposition of these cyclic sequences. Regional stratigraphic correlation between studied sectors was constructed (Figure 7), and revealing the missing of Oligocene sediments from the sector 5 and its vicinity. Also high and low topographic area could be seen which could have been fault bounded.

\section{Discussion}

On correlating representative columns from each sector (Figure 7), the strato/structural picture can be seen and tectonic activity possibly occurred in the form of regional inversion effects. This inversion can be seen by the dip of the Late Eocene Unconformity in the direction the Miocene sediments are thickening. Another possible inversion have occurred around sector 3 .

On the basis of the hypothetical regional tectonic stages of the study area (Figure 8), the possible tectonic inversion which can be seen by the uplift of the Eocene stratigraphic section (Darnah Formation) of sectors 5 and 8, persisted from Late Eocene to Late Miocene (Figure 8 stages 2 - 5). Hence, no further deposition took place in these sectors. Whereas, in sectors $(1-4)$, where the sea transgressed from NW to SW directions, OligoceneMiocene sediments were much more common, giving rise to a subsidence phase in Early Oligocene (Figure 8 stage 3) and the deposition of Shahat Marl and Algal Limestone of the Al Bayda Formation. Further faulting was activated to the SW direction move up sector 3, and depressing down sectors 1 and 2 which acted as depositional sites for Limestone of Al Abraq and Faidyah Formations of Late Oligocene and Benghazi Limestone Member of Middle Miocene (Figure 8 stage 4). Further subsidence and advancement of sea in the vicinity of sectors 1 and 2 to deposit the Limestone of Qattarah Member (Figure 8 stage 5), while area of sector 3 was an uplift. A persisted regional fault have separated sectors 1 , 2 and 3 from sectors 4 to 8 at Late Miocene or even younger time.

It is important to validate that the structure dominating the area in question is actually an inversion feature (Figure 8), because reactivated faults have prospective stratigraphic relationships. However, inversion is sometimes difficult to recognize when uplift area has occurred to the point where erosion has removed any indication of the original thickening associated with faulting. The uplift was accommodated by large fault zones bordering the inversion zone (Figure 8, stages 2 - 5). This style of inversion and shortening may have contributed to the creation of the high elevations of the Eocene section in the study area $(>300 \mathrm{~m})$ and the missing of the Oligocene section.

The study area (sector 5) may have been uplifted/inverted by the culmination of several phases of deformation:

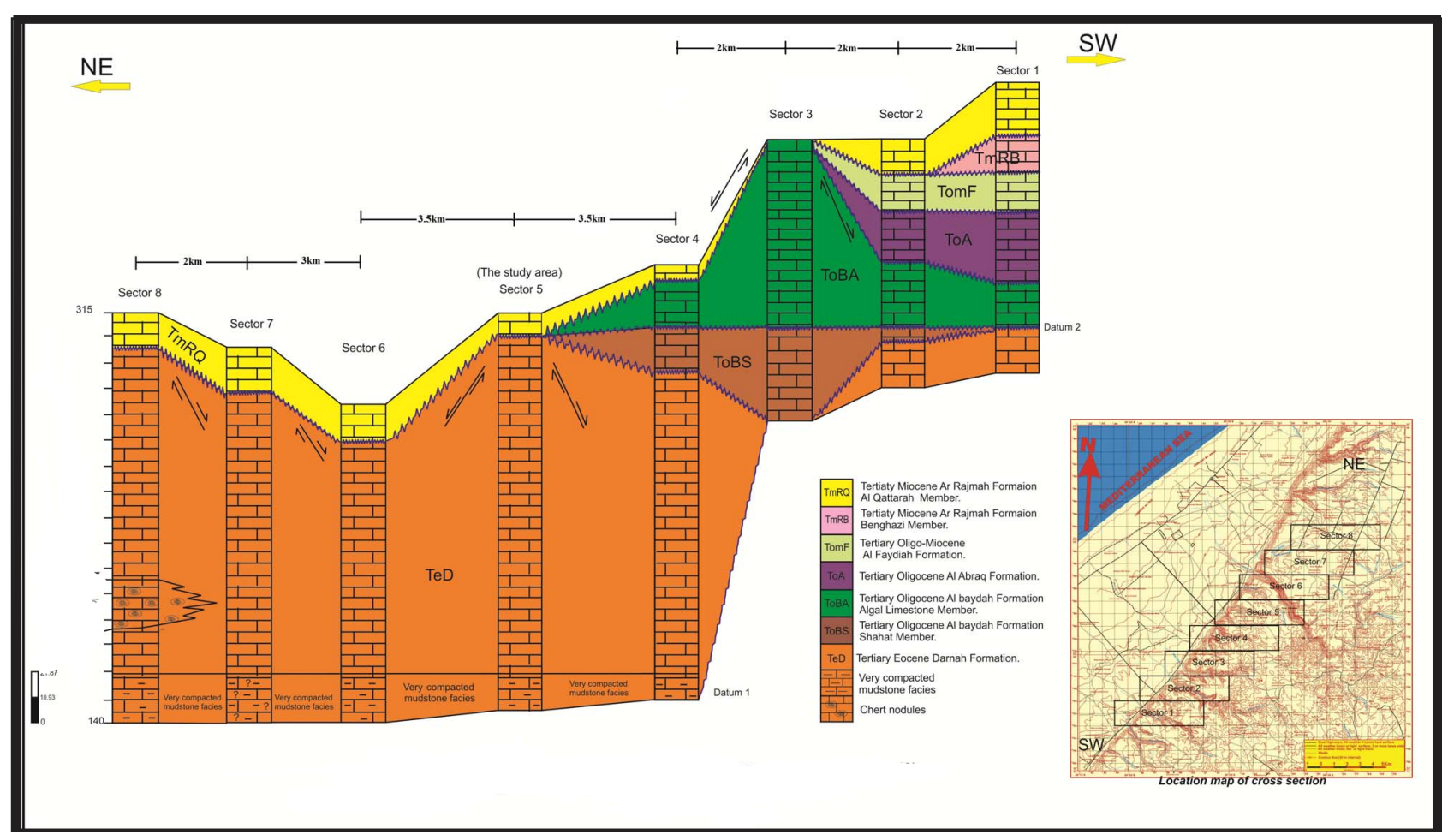

Figure 7. Regional strato-structural correlation between sector (1) to sector (8), Deryanah-Al Abyar area, Al Jabal Al Akhdar, NE Libya. 


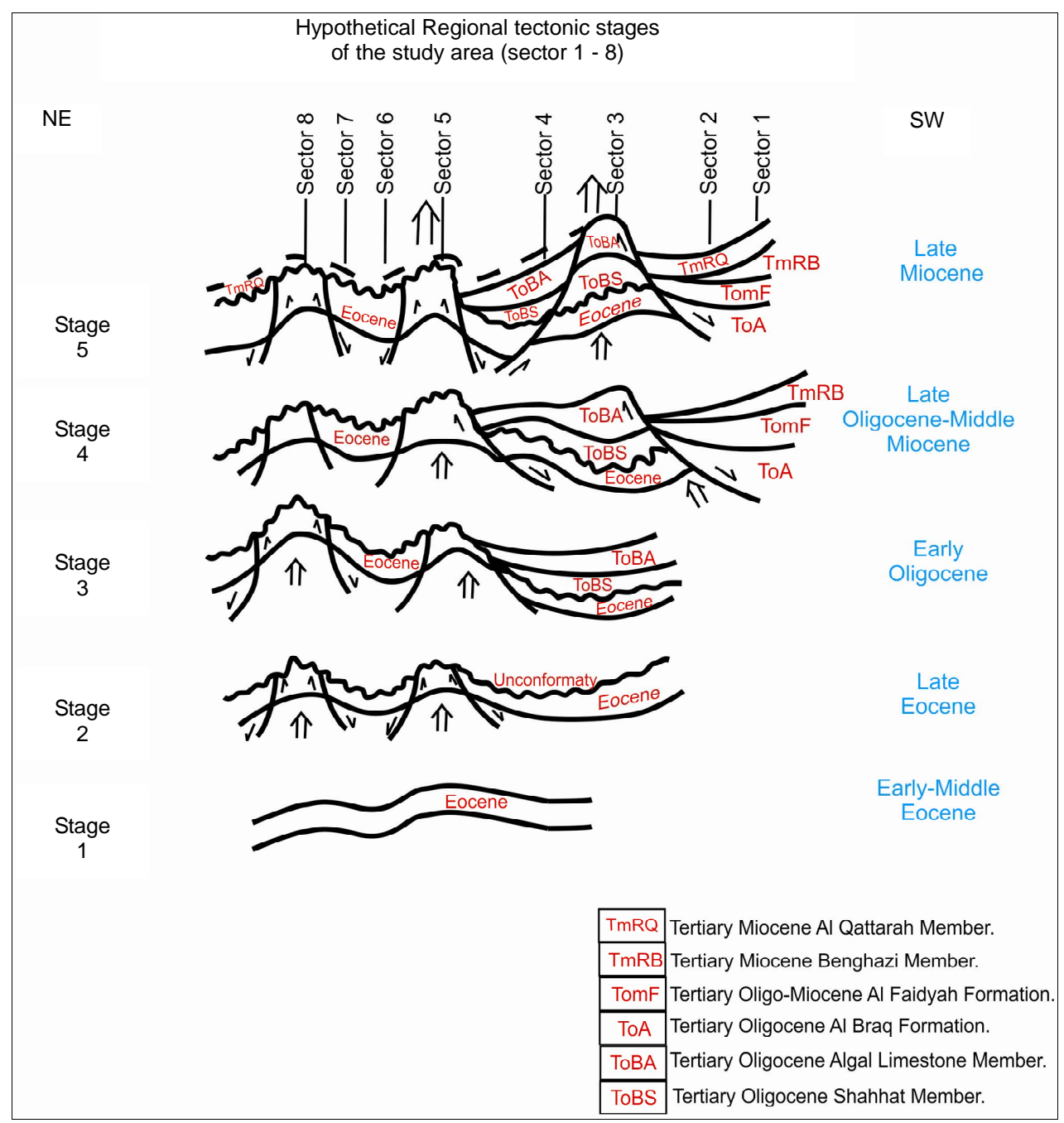

Figure 8. Hypothetic regional tectonic stages of the study area.

an uplift phase in the Late Eocene, to subsidence in the Early Oligocene, to a major uplift/inversion phase in the Late Oligocene-Middle Miocene and recent deformation in the Neogene-Quaternary. The region of this study area was previously part of the shelf margin of northern Al jabal Al Akhdar basin and has been uplifted and translated to be a part of Cyrenaica platform to the south.

The variability in vertical sequence architecture and of lateral change of lithologic units between sectors in NE-SW direction (Figure 7) suggests that the tectonic activity continued during the deposition of the Oligocene-Miocene sediments. Moreover, the concentration of these sediments in sectors 1 - 4 (Figure 7) would infer the sea pathways were coming from the SW direction.

\section{Conclusion}

From this study, the missing of the Oligocene section from sector 5 and its vicinity could be attributed to Late Eocene-Oligocene uplift resulted in severe widespread erosion of the Oligocene sediments. The result of this study is an illustration of the occurrence of possible small-scale tectonic activity during periods, which were previously thought to be tectonically calm. Furthermore, accurate dating of the onset of the orogenic phase, which caused inversion and uplift in the study area during the Late Eocene to Late Oligocene, is not possible without additional data.

\section{Recommendations}

Because of the fact that this study was only an attempt to find out that reason behind the missing of the Oligocene section in sector 5 , and until now, it was assumed that this missing may be due to tectonic movements in the area started close to the end of the Eocene. However, sea level variations have to be interpreted in detail from outcrops, and a detailed sequence stratigraphic framework, with good biostratigraphic control, needs to be constructed. 


\section{Acknowledgements}

The authors would like to thank the Department of Earth Sciences, University of Benghazi for providing most of the data used in this study. Deep thanks are also extended to anonymous reviewers for their constructive comments and thoughtful discussions on this paper.

\section{REFERENCES}

[1] A. S. El Hawat and M. A. Shelmani, "Short Notes and Guide Book on the Geology of Al Jabal Al Akhdar Cyrenaica,” NE, Libya, 1993, 70 p.

[2] "Geological Field Studies. Detailed Outcrop Information from Sectors 1-4 and 6-8," University of Benghazi, Benghazi, 2010.

[3] E. Klitzsch, "The Structural Development of Parts of North Africa since Cambrian Time,” 1971.

[4] A. Michard, “Eléments de géologie Marocaine,” Éditions du Service Géologique du Maroc, 1976, 408 p.

[5] M. Mattauer, P. Tapponnier and F. Proust, "Sur les Mécanismes de Formation des Chaînes Intracontinentales. L'exemple des Chaînes Atlasiques du Maroc,” Bulletin de la Société Géologique de France, Vol. 7, No. 19, 1997, pp. 521-526.
[6] M. Bensaid, J. Kutina, A. Mahmood and M. Saadi, "Structural Evolution of Morocco and New Ideas on Basement Controls of Mineralization," Global Tectonics and Metallogeny, Vol. 3, 1985, pp. 59-69.

[7] A. Pique, M. Dahmani, D. Jeannette and L. Bahi, "Permanence of Structural Lines in Morocco from Precambrian to Present,” Journal of African Earth Sciences, Vol. 6, No. 3, 1987, pp. 247-256.

[8] R. Westaway, "Present-Day Kinematics of the Plate Boundary Zone between Africa and Europe, from the Azores to the Aegean," Earth and Planetary Science Letters, Vol. 96, No. 3-4, 1990, pp. 393-406. doi:10.1016/0012-821X(90)90015-P

[9] W. Beauchamp, M. Barazangi, A. Demnati and M. El Alji, "Intracontinental Rifting and Inversion: Missour Basin and Atlas Mountains, Morocco,” AAPG Bulletin, Vol. 80, No. 9, 1996, pp. 1459-1482.

[10] R. Brede, M. Hauptmann and H. Herbig, "Plate Tectonics and Intracratonic Mountain Ranges in Morocco-The Mesozoic-Cenozoic Development of the Central High Atlas and the Middle Atlas," Geologische Rundschau, Vol. 81, No. 1, 1992, pp. 127-141. doi:10.1007/BF01764544

[11] P. A. Ziegler, "Geological Atlas of Western and Central Europe,” Shell International Petroleum, The Hague, 130 p. 